\title{
EU enlargement in 2004 - a time to revisit transition challenges
}

\section{Klaus Liebscher}

The OeNB's East-West Conference 2003, on which this book is based, looks back at an impressive history. The first OeNB seminar focusing explicitly on the transition economies in Central and Eastern Europe took place in October 1989, not long after the opening of the iron curtain. Since 1995 the conference has been an established annual event, serving as an international forum in which leading experts from government and international organizations, central and commercial banks as well as universities and research institutes discuss questions related to the transition process and to EU enlargement.

Previous conferences dealt with all the major topics relevant for European integration and enlargement: the restructuring of the banking system, financial crises, the convergence progress, regulatory aspects of transition and other structural challenges, the quest for an adequate policy mix and the challenges of transition in general. The range of topics is, however, not just impressive because of its broad coverage, it also reflects the evolution of the transformation process. Some of the earlier conference topics, as for example the regulatory aspects of transition or issues related to institution building, have lost importance over recent years, given the successful completion of the major transition steps in these areas.

At the same time, we have also seen the focus shift from purely transition-related topics toward a more global perspective and a more horizontal approach to specific topics. The most recent conferences proved especially rewarding owing to the exchange of views and research cooperation among experts from transition and industrialized countries.

On several occasions, the Oesterreichische Nationalbank co-organized the conference with other institutions, such as the IMF, the Institute of International Economics, the Banca d'Italia or The Vienna Institute for International Economic Studies. The conference of 2003 (like that of 2000) was co-hosted by the Joint Vienna Institute (JVI), the Vienna-based provider of training in transition issues for central bankers, government officials 
and private sector representatives from countries in Central and Eastern Europe and from former republics of the Soviet Union.

The JVI, launched in 1992 by five international organizations and the Austrian authorities to respond rapidly to the large demand from economies in transition for training in market economics and the free enterprise system, and the OeNB look back at a long history of cooperation. The Austrian authorities have recently provided the JVI with a new building that meets the technology and accommodation requirements of a modern training facility. This new location, which has been in use since May 2003, will guarantee continuity in training for the years to come. We are especially pleased that we had the opportunity to combine the official opening with the 2003 East-West Conference.

About 15 years after the first seminar in the spirit of the East-West Conference, we stand at a point where the most important step of EU enlargement, one major focus of the conference series, is only a few months ahead. In May 2004, ten countries will join the European Union. This enlargement round is not only the most important one to date in terms of scale, diversity and economic growth potential, but also - as Commissioner Verheugen once put it - the best prepared in the history of the European Union.

The challenges facing Europe in the coming years and decades are manifold, complex and exciting. It is these challenges, tasks and prospects that the East-West Conference series is designed to address. We are convinced that the conference has played a significant role in providing a forum for discussion among experts and politicians from Western Europe and the current and future acceding countries, especially in times when the enlargement project that we are facing now still sounded like an overly visionary project.

With the most important wave of enlargement about to become reality, I believe that this is the opportune time to revisit. Consequently, the topic of the 2003 conference 'The Economic Potential of a Larger Europe - Keys to Success' was meant to cover the most important topics of previous East-West Conferences, including issues such as human capital formation, financial stability, the specification of a suitable policy mix or structural reforms - topics that are key to a successful transition process and therefore also to the provision of a prosperous growth environment within a larger Europe.

On the eve of the upcoming EU enlargement, we looked at these increasingly relevant topics from two perspectives. On the one hand, we investigated the importance of the before-mentioned factors for the success of the past integration process within the European Union as well as for the ongoing transition process in the current group of acceding countries. On 
the other hand, we also took a forward-oriented approach and addressed the challenges ahead. In this respect, not only did we focus on the SouthEastern European countries that are already on the accession track, but also debated the role the European Union and the Eurosystem can play in fostering the cooperation with and in promoting reforms in the countries as summarized under the 'Wider Europe' strategy of the European Commission - Russia, the Ukraine, Moldavia, Belarus and the Southern Mediterranean region.

While the formal enlargement of the European Union is scheduled for May 2004, an 'enlarged Europe' has already become reality for all of us in many respects. Preparations for the final step have been progressing steadily and I can imagine that many representatives from the acceding countries feel as if they were part of the European Union already. To mention just one example: delegates from the acceding countries have observer status in all European System of Central Banks (ESCB) and EU committees and thus closely follow the discussions about the future challenges of economic and monetary policy.

We appreciate the medium-term prospect of a number of new members joining the euro area. Of course, they will have to fulfil the same conditions for EMU accession as earlier members did, which are: European Union membership, participation in ERM II for at least two years without severe tensions and sustainable compliance with the Maastricht criteria. These are sensible and sound milestones on the route to full monetary integration.

As to the single monetary policy, sticking to the primary objective of maintaining price stability remains a key factor for the credibility of both EMU and the euro. By maintaining price stability, monetary policy makers optimally contribute to enhancing the long-term prospects for economic growth and thus also employment in the euro area. Even though the shortterm nominal interest rates are at the lowest level in 50 years, inflationary expectations are in line with our definition of price stability. At this juncture, it may, however, be particularly warranted to stress that monetary policy cannot by itself generate lasting and sustainable growth and employment in the euro area. To stimulate the economy and employment, economic policy makers are called upon to devise adequate structural measures that tackle the fundamental weaknesses and set off pressing adjustments.

Whereas EMU entails a common monetary policy for all of its members, fiscal policy continues to be formulated and executed at the national level. Fiscal policy must be part of a comprehensive and growth-oriented strategy that focuses on improving the structure of public expenditures. Besides, we must continue to credibly meet the provisions of the Stability and Growth Pact, which is crucial for the smooth functioning of EMU. Let me 
emphasize that in a monetary union we need fiscal policy rules to prevent one country's unsound fiscal policy from negatively impacting on other members of the monetary union. What is more, our complying with the Stability and Growth Pact not only favours other countries but also future generations, which is particularly important in those countries where population ageing is a significant phenomenon. Against the grain of some critics of the Stability and Growth Pact, I am strongly convinced that the Pact is sufficiently flexible to support budgetary discipline also in economically difficult times. Without the Stability and Growth Pact, EMU would - in my opinion - suffer from a 'design flaw'.

Let me conclude with expressing my conviction that the enlargement of the European Union and the economic and monetary integration of the acceding countries will not only strengthen the role of the European Union as a global player in the long term, but also make a sustainable contribution to stability, peace and welfare in Europe. 